\title{
The Behavior of Islamic Producer in Supplying Halal Food at Laziza and Waroeng Steak and Shake Surabaya
}

\author{
Arin Setiyowati $^{1 *}$, Kholifatu Azqiya $^{1}$, Umriyah $^{1}$ \\ ${ }^{I}$ Department of Islamic Banking, Muhammadiyah University of Surabaya, Surabaya, Indonesia \\ *Corresponding author. Email: arin.st@fai.um-surabaya.ac.id
}

\begin{abstract}
Halal products become a global Issue. Indonesia is a big market for halal products and the legalization of regulations in Halal products. The attraction between the behaviour of consumers and producers on the awareness of making halal products as a lifestyle in their economy further strengthens the position of halal products in goods, especially food in Halalan Thoyyiban as a trend among the millennial generation. This research aims to analyse how the Behaviour of Islamic producers in producing of Halal Food. The case studies were conducted at Laziza and Waroeng Steak and Shake (WSS) Surabaya. This research used a field research approach and a qualitative approach. The research type was a case study expected to be able to explore data in-depth on the producers' behaviour, especially the process of producing and marketing of halal food, thereby attracting consumers by marketing halal food chicken and steak. The Results are Laziza and Waroeng Steak and Shake that Laziza and Waroeng steak and shake Surabaya has fulfilled the norms and ethics in Islamic production, as well as applying its values in the production and promotion of halal food. The significance of this research could be the prototype of a successful food business that applies the concept of Islamic production.
\end{abstract}

Keywords: producer behavior, Halal Food, Laziza, Waroeng Steak and Shake

\section{INTRODUCTION}

The growth in demand for halal products has triggered the development and application of the halal industry not only in Muslim-majority countries but also in countries with a majority of non-Muslims. Halal Lifestyle is no longer religious guidance for Muslims, but a lifestyle of modern society. It has a significant contribution to the world economy; there are food sectors, finance sectors, travel sectors, cosmetic sectors, tourism sectors, fashion sectors, and others.

The Global Islamic Economy reports that the nominal expenditure of 218.8 billion US dollars in 2017 represents Indonesia as the largest halal industry market. Although Indonesia is globally still unable to surpass the rank of 10 of the 15 highest countries in the development of Islamic economics. Although Indonesia is a country with a Muslim population of 209.1 million people or $87.2 \%$ of the total population [1].

In 2017, spending on Indonesian halal food and beverage products was the largest sector, reaching 170.2 billion US dollars. With a contribution of around 3.3 billion US dollars from Indonesian exports to member countries of the Islamic Cooperation Organization (OIC) [2].

Halal is defined in the holy Quran and the Sunnah (the Prophet's saw) actions, sayings, and tacit approval and is a dietary obligation for Muslims. Important principles about halal and haram (unlawful), such as the things permissibility on fundamentals. Thus, to make lawful and to prohibit is the right of Allah alone. It also prohibits the halal and permits the haram. It against the fundamentals and general principles of faith. The prohibition is due to their impurity and harmfulness. If halal is sufficient, while haram is superfluous, whatever it is leading to haram, falsely representing prohibition of the haram as halal. A good intention is to make the haram acceptable; to avoid doubtful things; to prohibit haram for everyone alike, regardless of the school of thought; and necessity dictates exceptions [3]. Muslim consumers need to have a positive attitude and awareness of halal food consumption as it is part of the religious obligation. The attitude of consumers, mainly Muslim consumers, will contribute to the future of the halal industry in this country, including Indonesia [4].

In today's society, the increasing concern over health promotes the acceptance of halal food as it covers the full understanding of consuming clean and hygienic food to promote better health. Consumers today are more aware of the importance of health, thus influence their behavior on food consumption. They search for food that can keep them healthy and improve their mental state as well as their quality of life. In Islam, consuming halal food constitutes an essential aspect of religion. The role of food in cultural practices and religious beliefs is complicated but has a unified understanding among Muslim followers. For instance, the halal logo or label communicates and convinces Muslim consumers that the food product is produced and prepared according to the Islamic requirement. On the other hand, the non-Muslim consumers understand those food items carrying the logo are prepared most hygienically and clean consumption. Furthermore, it has also been proven that non-Muslim consumers do respond positively to halal food certification [5].

In Indonesia, Laziza is one of the food restaurants that has a halal label with a franchise business system. While Waroeng Steak and Shake is a chicken and meat food 
restaurant with a Western-style steak concept, but the concept of Islamic business and halal food products is already certified. It means that both of them have proven the guarantee of tayyiban halal food products with various criteria.

From this phenomenon, the researcher intends to analyze the behavior of halal food producers, both in producing and campaigning for halal food products to the public. In this case study at Laziza Keputih and Waroeng Steak and Shake (WSS) Surabaya, the food producers have been certified with MUI halal certification and supported by patterns another producer behavior. It was interesting to write since it was a reference or prototype of MSME halal food products with social prospects.

\section{METHODS}

Based on the type of problem written and its purpose, this study uses qualitative methods. The objects in this study are Surabaya's Laziza Keputih outlet and Surabaya's Waroeng Steak and Shake. The samples were two objects in representing producers who carry out Islamic production activities, especially in halal food products.

In collecting data, this paper uses observation, in-depth interviews, and documentation. The object of the informants in this study is the operations manager, employees, and consumers of the two research objects, namely Laziza and Waroeng Steak and Shake (WSS).

The data analysis technique of researchers uses data triangulation, namely passive participatory triangulation. It means that the researcher is passively involved in the production process; the researcher treats observers, consumers, directly, and as diggers [6].

\section{RESULTS AND DISCUSSION}

\subsection{Laziza Kenjeran Surabaya}

Laziza is one of the names of food outlets that focus on fried chicken. Since its establishment in 2015, Laziza already has 35 stores spread across various cities in East Java. Among them are Surabaya, Sidoarjo, Gresik, Pasuruan, Probolinggo, Jember, and Madiun. The business concept brought by Yudha Setiawan, as the owner of Laziza fried Chicken, is the business concept of 'Rahmatan Lil'aalamiin', meaning that the existence of Laziza is professional and awaited by many people. This concept is implemented through the "Eat Free Pay Prayer" program, which is an alms program for Muslims who are running the Sunnah fasting Monday-Thursday with free open on Laziza. This program is one of the promotion types of Laziza. By applying the principles of corporate-style management, with one command. Because there is centralized management, the way marketing, finance, and others are standardized. Many are not able to make financial reports, even though this is crucial in business. Therefore, every partner who is interested in doing Laziza business is truly pure as an investor. While the financial statements and various other operational matters directly from the center. We manage people's funds so they must be transparent and ready to be audited.

In terms of marketing, Laziza carries the concept of spiritual marketing, in which the price of Lazizaa products must be lower; the menu is made more varied. Besides, in terms of HR management, Laziza treats every employee as a santri, so they must follow the applicable rules, including female employees who are veiled, must uphold prayers.

Related to the management of its production, especially in this aspect of halal food, Laziza includes goods or ingredients on the existing food menu and allowed in Islam. The main menu of this Laziza restaurant is chicken obtained from suppliers of PT. Reza Perkasa, where Laziza restaurant has received the material after slaughtering it and using the transportation to transport the chicken, is specifically for transporting chicken slaughtered to the supplier.

Based on the results of interviews with informants confirmed that Laziza's main menu is chicken, rice, french fries, and in our restaurant has been certified halal to ensure halal and fulfillment of good nutrition for consumers.

Furthermore, the aspect of halal food from how to obtain it, based on the results of interviews with informants as operational managers, that halal methods obtained the goods consumed, not the results of stealing, corruption, deception, and others. Related to the main capital Laziza came from the Hidayatullah boarding school. Laziza is a franchise business or restaurant franchise from Yudha Setiawan as the owner of Laziza.

In the halal characteristics in terms of processing the production material, namely food ingredients, Lazizaa processes the main ingredients (chicken cut) from the supplier of PT. Reza Perkasa, measuring the chicken meat, frying it, then serving it to consumers [7].

In the process of processing food ingredients, Laziza already based on SOP. Including employees must wear hats so that hair does not fall on the food to be served, cooking gloves and chicken meat tongs to maintain food hygiene, and wear masks. It has become an absolute rule in efforts to maintain quality in the processing of food ingredients that are clean and lawful [8].

Next is Thayyib's characteristics that Laziza has fulfilled as follows [9].

a. Healthy food. The food menu offered by Laziza already has good levels of nutrition for the body, the nutritional content of chicken as the main menu is that every 100 grams of chicken meat there is $74 \%$ water $22 \%$ protein, calcium, phosphorus, iron, also rich in vitamin A.

b. The menu served is proportional. The menu served is following the portion of the meal in general, the average menu ordered and eaten in a place that rarely leaves the food makes it proof that the menu served is proportional. And this is a condition with the spirit of la tabdzir (not excessive) in consuming.

\subsection{Waroeng Steak and Shake Surabaya}

Waroeng Steak \& Shake (WSS) was founded by a married couple Jody Brotosuseno and Siti Hariyani. With prices that are affordable by students and the lower middle class, as 
well as quality food that competes with other steaks, this Waroeng Steak and Shake is growing rapidly. From 4 September 2000 until now, Waroeng Steak and Shake outlets have grown to 80 outlets throughout Indonesia from Medan to Makassar.

Besides, Waroeng Steak and Shake always prioritizes the halal status of all food ingredients and drinks. Even with local ingredients, Waroeng Steak and Shake (WSS) can present a high taste of typical Europe at prices that reach the people of Indonesia. Price transparency is proven by clearly placing a price list in front of the outlet so that potential buyers can find out their low menu prices.

If it is related and analyzed in terms of Islamic production, then one of the principles that are the focus of the writer's discussion is the promotion of halal food products conducted by the research object, namely Waroeng Steak and Shake (WSS) in Surabaya.

In terms of halal and thayyib in terms of delicious, Waroeng Steak and shake has implemented an important point in terms of production, namely ensuring that the food ingredients used are good ingredients and guaranteed halalness. Evidenced by the overall production input using ingredients such as meat, both beef, and chicken. Also, WSS guarantees the ingredients used and presented to consumers are good ingredients and halal guaranteed. The effort was realized by registering their outlets for inspection by the MUI to get the MUI Halal certificate made by the management of Waroeng Steak and Shake, to ensure the legality of halal food for consumers [10]. It is stated on the product packaging and nameplate in front of each Waroeng steak and shake outlet.

Besides being Halal because of its deliciousness, Waroeng Steak and Shake also fulfills the halal characteristics of its production process [5]. Based on the results of data from the informant confirms that the meat is cooked or processed the production of slaughtered meat by the name of God. It was maintained by choosing a reliable meat and chicken supplier and a good Muslim owner. In addition to meat, vegetables produced are also fresh vegetables. Vegetable suppliers directly deliver vegetables every day to the outlet. The use of meat also has its criteria, both in terms of shape and need, according to consumer orders.

In terms of price, Waroeng Steak and shake not only prioritizes profit but also prioritizes Mashlaha both for consumers and the environment at large. Prices are competitive and not excessive compared to food outlets that sell Waroeng steak and shake type menus [11]. Based on the observations of researchers, that the price determination of Waroeng Steak and shake high school and college students can reach food products.

Another interesting thing about Waroeng steak and shake is the aspect of promotion. It was different from most other culinary businesses, where WSS does not put up promotions or advertisements that merely attract consumers, without being matched by quality products and services excellent. Waroeng Steak and shake is the way to promote it to maximize the quality of products and services, which ultimately can become WSS marketing capital in the form of customer satisfaction who have visited outlets so that it can provide sustainable growth in this WSS in the future. Besides that, another unique thing is the design outlet. It placed in many corners of this WSS outlet, small boards, ornaments and wall hangings. Islamic economic culture campaigns loaded with Islamic editors, especially in consumption, loaded with the invitation of goodness kindness (Amar Ma'ruf) as a small part of optimal service to consumers.

In a service to consumers, there will be some ethics according to Didin Hafidudin and Kartajayawhich quoted as an informant. They stated there are Islamic values applied in providing maximum services. They should work professionally/ maximally and fully, commitment and sincerity, behave politely, hospitality, speech correctly, to be honest/never lie in carrying out all transaction activities, and to have responsibility in carrying out duties and obligations.

Based on research data, especially in terms of service, if WSS employees do not feel comfortable in producing ordered food, then those orders will be replaced with a menu according to the initial order. It prioritizes honesty in Waroeng Steak and Shake in doing business with completed efforts monitoring and evaluation so that the business can run smoothly.

\subsection{Producer Behaviour}

In producing, Islam has a direction on Islamic values that must be taken care of by the producers themselves, including: [8]

a. Long-term insight, oriented towards the afterlife goal;

b. Keeping promises and contracts, both in the internal or external scope;

c. Meet the measurements, accuracy, accuracy, and truth;

d. Sticking to discipline and dynamic;

e. Glorify achievement/productivity;

f. Encouraging ukhuwah between economic actors;

g. Respecting individual property rights;

h. Following legal and contract/transaction legal requirements;

i. Fair in transactions;

j. Having social insight;

k. Payment of wages on time and reasonable;

1. Avoiding types and production processes forbidden in Islam.

The focus of analysis for the two samples is the behavior of producers in campaigning for halal food products, which of the twelve Islamic values are contained in the twelfth point, namely Avoiding the types and processes of production that are forbidden, which starts from the input of production, process, presentation to promotion that adjusts Islamic values in production.

The application of these values in production will not only bring profit to producers but will also bring blessings [11]. The combination of benefits and blessings obtained by producers is a Mashlahah that will contribute to the achievement of Falah. In this way, the producer will get ultimate happiness, that is glory not only in the world but also in the hereafter [12].

The application of the above values in production will not only bring benefits to producers but also bring blessings. The combination of benefits and blessings obtained by producers is a mashlahah that will contribute to the achievement of Falah. In this way, the producer will get 
ultimate happiness, that is glory not only in the world but also in the hereafter. Mashlahah in Islamic Production is decreasing from Total Revenue (TR), Total Cost (TC) and Berkah Cost (BC). It means that the Islamic producer is Mashlahah Maximizer, not only profit-oriented but also Berkah oriented.

Based on the data in the previous two points, specifically on the behavior of producers in producing and promoting for halal food products. It is of course they have implemented Islamic values on the twelfth point, namely avoiding types and production processes forbidden in Islam, namely in a variety of chicken and steak-based foods, both Laziza and Waroeng Steak and Shake.

In addition, the norms and ethics that have been practiced by producers (Laziza and WSS) in production activities, especially halal food products based on chicken and steak (meat).

Both Laziza and Waroeng Steak \& Shake in the process of input of production materials have paid attention to halal haram, thayyib for consumer health, by entrusting the supplier of input materials to a trusted supplier in maintaining halal in the process of slaughtering chickens, cleanliness and the quality of other ingredients. In the process of producing input materials, both have SOP (Standard Operating Procedures) in ensuring the quality of processed food. Food products, both chicken and steak, are good and useful for the health of consumers in general.

In terms of services, Laziza and WSS apply humanistic services to consumers, in addition to the Islamic outlet design that is ornaments that contain the proper food preaching in Islam, the Mushola facility at WSS that supports consumers in carrying out their prayer obligations on time. It means that the design and service in Laziza and WSS bring the truth closer, closer to the world, and the hereafter.

Besides, the Laziza program is free on Monday-Thursday (the free meal program pay for prayer), meaning that in the business process, it uses ethics that is not merely profitoriented but also implements socially-oriented programs. Besides the program, in determining the price of food products, Laziza and WSS also use affordable prices for pockets of students, meaning that it reached by both the middle and lower classes. This means that the Laziza and WSS business concepts, as well as harmonizing individual welfare and general welfare can be achieved through affordable prices. This part of Berkah cost that must they do to get Mashlahah maximize.

In terms of promoting food products, Laziza and WSS do not use hyperbolic promotional patterns to attract consumers. Precisely, Laziza and WSS implemented an honest promotion, meaning that the prices displayed in front of the outlets. It matched the real prices of halal food products as well as promotions that direct consumers to buy with the concept of halal food products with Islamic business that suits the needs of the community.

So, based on research data shows that the behavior of both Muslim producers Laziza and WSS in producing and campaigning for halal food products have paid attention to and fulfilled all the rules set in Islam.

\section{CONCLUSION}

Based on the analysis of research data on the behavior of producers in producing and promoting halal food products, Laziza and Waroeng steak and shake Surabaya has fulfilled the norms and ethics in Islamic production, as well as applying its values in the production. They promote of halal food products with different methods, it began producing, service, philanthropy program and promoting that used Islamic compliance to make a success business in Chicken and Steak (Meat) based food. This research is different from previous studies, considering that the field research has never been done by researchers before. Suggestions for further research are the emphasis on proving quantitative gains of Mashlahah after reducing the cost of blessing.

\section{REFERENCES}

[1] P. M. Antara, R. Musa, and F. Hassan, "Bridging Islamic Financial Literacy and Halal Literacy: The Way Forward in Halal Ecosystem," Procedia Econ. Financ., vol. 37, no. 16, pp. 196-202, 2016.

[2] H. Living, "Halal Consumer In Indonesia : Nuruturing The 7 Forces Halal Way, October, 2018.

[3] M. Tieman and M. C. Ghazali, "Halal Control Activities and Assurance Activities in Halal Food Logistics," Procedia - Soc. Behav. Sci., vol. 121, no. September 2012, pp. 44-57, 2014.

[4] A. A. Khalek, "Young Consumers' Attitude towards Halal Food Outlets and JAKIM's Halal Certification in Malaysia,” Procedia - Soc. Behav. Sci., 2014.

[5] V. N. Mathew, A. M. R. binti A. Abdullah, and S. N. binti M. Ismail, "Acceptance on Halal Food among Non-Muslim Consumers," Procedia - Soc. Behav. Sci., vol. 121, pp. 262-271, 2014.

[6] S. R. Tika Widiastuti, "Model Pendayagunaan Zakat Produktif oleh Lembaga Zakat dalam Meningkatkan Pendapatan Mustahiq,” Jebis, vol. 1, no. 1, pp. 89-102, 2015.

[7] S. G. Alqudsi, “Awareness and Demand for 100\% Halal Supply Chain Meat Products," Procedia - Soc. Behav. Sci., vol. 130, pp. 167-178, 2014.

[8] W. SARI, "Produksi, Distribusi, Dan Konsumsi Dalam Islam,” Islam. J. Ekon. Islam, vol. 5, no. 2, pp. 1-34, 2014.

[9] M. Ali, "Konsep Makanan Halal dalam Tinjauan Syariah dan Tanggung Jawab Produk Atas Produsen Industri Halal," AHKAM J. Ilmu Syariah, vol. 16, no. 2, pp. 291-306, 2016. 
[10] D. Sari and I. Sudardjat, “Analisis Pengaruh Labelisasi Halal terhadap Keputusan Pembelian Produk Makanan Impor dalam Kemasan pada Mahasiswa

Kedokteran Universitas Sumatera Utara," J. Ekon. dan Keuang., vol. 1, no. 4, pp. 49-56, 2013.

[11] P. P. Islam, "Perilaku Produsen Islam ISSN : $2477-$ 6157,” vol. im, pp. 37-49, 2011.

[12] D. Hafiduddin et al., "Implementasi Prinsip Produksi Ekonomi Islam Pada Mebel Ira Bersaudara Kota Bengkulu. PEN,” vol. 5, no. 1, pp. 1-14, 2019. 